\title{
Brief notes on the main archives used
}

\section{Archdiocesan Archives of Mechelen, Belgium}

The archdiocesan archives of Mechelen hold fifteen large boxes of manuscripts relating to the English convent of Brussels (file ref: Kloosters, Engelse Benedictinessen). They contain account books, ceremonials, examinations of novices before profession and many other texts on various aspects of the daily life of the house. But the gems of this collection are the contents of boxes 12/1 to 12/4: the manuscripts of the protracted dispute which divided the convent in the 1620s and 1630s. These boxes gather hundreds of letters, written by Abbess Mary Percy and her supporters, and by the nuns who opposed them, to their archbishops, Mathias Hovius (1596-1620) and Jacobus Boonen (1621-55). The correspondence also includes the answers written by clerics such as Robert Chambers, Anthony Champney, Gabriel Colford, Edward Lusher or John Norton, either to the nuns or to the archbishops. Lengthy visitation reports add details to the picture of this fractious house, with the official testimony of each nun answering the questions of the visitor. The documents are written in English, French and Latin, with a few in Dutch, Spanish or Italian. A carefully selected sample of the most representative papers, edited and translated, will be published as part of a volume comprising further documents relating to the Brussels controversy; see Jaime Goodrich, Laurence Lux-Sterritt and Paul Arblaster (eds), The Babylon of Brussels: Spiritual Controversies among English Benedictines, 1609-1642 (Toronto: PIMS, forthcoming). 


\section{Archdiocesan Archives of Westminster, England}

In the Westminster collection, box YYG complements what can be found at the Mechelen archive on the Brussels dispute. But the real specificity of the documents held at Westminster is that they illustrate the link between the convents and the mission. They provide a revealing glimpse into the fact that nuns kept themselves well informed of on-going religious controversies and read a number of treatises relating to the mission in England. Box C.17, for instance, contains a copy of Edward Dicconson's 'Account of the English Mission' and 'Collections out of English Historians' as well as writings about the English Acts of Parliament and penal laws meant to punish the practice of Catholicism on English soil. The file also contains discussions of a more theological nature, on transubstantiation, Holy Communion or Jansenism. There are several copies of letters on topical points of controversy, but also more practical documents of spiritual guidance, on the distribution of time or how to take the Spiritual Exercises, for instance. Most documents are written in English but many are in Latin.

\section{Archives départementales du Nord, Lille, France}

The papers held in this county archive were seized from the Cambrai nuns in the aftermath of the French Revolution, and prior to the nuns' return to England. Boxes $20 \mathrm{H}-1$ to $20 \mathrm{H}-59$ contain thousands of manuscripts, most of which are of a spiritual nature and reveal much detail about the Bakerite spirit of that house. As is the case in all of the collections cited here, the contents of each box can be very diverse, with no apparent sequence or unity of topic or date. Among other precious papers, this archive holds manuscript copies of the Rule of the Order and the constitutions of the community. It also has a very informative selection of manuscripts documenting the official proceedings for the election of abbesses, the admission of novices, the ceremony of profession and funerals; these documents reveal much about the various stages of a nun's life. The archive holds reports of visitations by the vicars-general and a large number of spiritual documents such as treatises on the virtues of a good nun, advice for spiritual retreats and prayer, exhortations against worldly affections, explanations of the mysteries of the Mass and many other writings reflecting the teachings of Augustine Baker. The documents are mostly written in English, and sometimes in French or Latin.

xxii 


\section{Archives départementales du Val d'Oise, Cergy-Pontoise, France}

These county archives hold the documents which were seized by the revolutionary officials who enforced the removal of the nuns at Pontoise. Unlike those held in Lille, which were obtained under similar circumstances, the manuscripts (twelve large boxes referenced $68 \mathrm{H}$ ) are not of a spiritual nature but, rather, illustrate, in French, the more pragmatic aspects of daily life in the cloister. Several manuscripts relate to the difficulties encountered by the founding party when they initially tried to settle in Boulogne, and the official licences to settle in Pontoise have been carefully preserved. There are also detailed account books, held by the nuns over the years, as well as documents about dowry payments made and due, annual pensions or property deeds. The very precise inventories of the furniture and contents of each room, drawn up by the officers in charge of the repossession, yield a wealth of information about the interior of the house.

\section{Bibliothèque Mazarine, Paris, France}

The collection held at the Mazarine library holds the ceremonial of the English Benedictines of Paris, approved by the archbishop, as well as the constitutions of the community. It also holds a manuscript catalogue of the books owned by the nuns in the seventeenth century, especially those recommended by Augustine Baker. In addition, there are copies of some of Baker's spiritual treatises. The ceremonial and constitutions are in French but the other documents are written in English.

\section{Diocesan Archives of Ghent, Belgium}

The manuscripts kept at Ghent are not as voluminous as those in the collections discussed above; overall, they testify to the tight bond between the Ghent convent and the Society of Jesus. They appear to indicate that the house was usually quite united when it took votes, for instance, on the matter of the election of the abbess, or when nominating clerics to represent it and act as translators and agents in the town (all of whom were Jesuits). The documents also show the great financial difficulties which plunged the convent into a cycle of considerable debt for years. Most manuscripts are written in Latin, and some in English. 


\section{Douai Abbey, Upper Woolhampton, England}

Douai Abbey is a monastery of Benedictine monks; in 2010 the community obtained funding allowing it to build a magnificent library and archive, in keeping with the most modern standards of conservation. The collection relating to the nuns accounts for over seventy boxes, spanning the life of several convents, from their origins to the present. Most are in English or French, with some Latin texts. Early modern manuscripts relate mainly to the communities of Ghent, Boulogne/Pontoise and Dunkirk, with some documents concerning the Brussels convent. One of the difficulties of researching this particular collection is linked to its diversity; Douai has accrued a veritable treasure of chronicles (such as 'The foundation of Bullogne', written by Lucy Knatchbull), house histories (Dom Marus Estiennot's 'Histoire des monastères des DD. Bénédictines angloises'), biographies of exemplary nuns (Tobie Matthew's 'Life of Lucy Knatchbull'), documents on house management (such as Anne Neville's 'Instructions to Superiors'), guide books (such as the ceremonials of the Pontoise and Dunkirk communities) and spiritual notes. There is no itemised catalogue of the archive's contents, rendering the process of researching painstakingly laborious. Yet, as one sifts through thousands of folios in order to get a better idea of the contents of each box, there can be no doubt that this archive is a veritable cornucopia of information.

\section{Downside Abbey, Stratton on the Fosse, England}

Downside Abbey's imposing buildings bear witness to the prestige of the Benedictine Order in the nineteenth century in the Somerset area. The library and archive building is a modern extension, housing a wealth of documents tracing the history of the Order from the Middle Ages to today. Regarding the manuscripts of English Benedictine nuns in exile, Downside holds precious texts documenting the spiritual life of the Cambrai community, most of them written in English. It holds octavo volumes written by Augustine Baker and by some of his followers at the Cambrai convent, mainly Gertrude More and Margaret Gascoigne. Amongst the collection are the four manuscript volumes written by Barbara Constable, 'Gemitus Peccatorum or the Complaints of Sinners', 'Considerations for Preests', 'Considerations and Reflexions upon the Rule of the most glorious father St Benedict', and 'Advices for 
Confessors and Spiritual Directors'. Some of the other documents have come from Haslemere and contain the necrologies of the Brussels nuns, as well as fragments of correspondence about the daily running of the Brussels house, the management of its properties and its dealings with the town authorities in order to be relieved of the payment of taxes.

\section{St Mary's Abbey, Colwich, England}

The Abbey of St Mary is home to a small community of nuns, the descendants of the convent initially founded in Paris. The archives, like those at Douai or Downside, are private but, unlike them, are not held in new buildings but, rather, within the enclosure of the convent itself. Access is therefore limited and the little archive room is not designed to accommodate several readers at once. This is a most wonderful archive. Hundreds of volumes, used by the Sisters of Paris and remarkably preserved, yield unique information about the spiritual life of both the community and its individual nuns. Early printed books tell us about what they read, while the manuscript volumes testify to how they lived. This collection is one of the few to keep several examples of personal notes or 'collections'. In these little manuscript books, nuns transcribed their favourite passages from sacred texts or sermons, compiled anthologies, added pious images as illustrations and wrote down their own thoughts and prayers. The archive also holds a record of Prioress Justina Gascoigne's addresses to chapter, as well as more official documents such as the house constitutions. Works of memory have been preserved, in the form of obituaries and house chronicles. The documents are written mainly in English and sometimes in French.

\section{The Bodleian Library, Oxford, England}

For the purpose of this book, I consulted some of the Thurloe papers (Ms Rawlinson A.36). The manuscripts were intercepted during the Civil War by agents of John Thurloe, head of the intelligence services during Oliver Cromwell's protectorate. They give a glimpse into the kind of information that is rarely found in conventual archives: in this case, the correspondence between Mary Knatchbull, abbess of the community of Ghent, and the representatives of Charles Stuart during his exile on the Continent. They show how 
the abbess of Ghent facilitated exchanges between Charles and his English supporters by concealing letters in amongst the convent's correspondence, and also how she allowed herself to volunteer both news and advice, as well as financial support. These documents are in English, and contain cyphered words.

\section{The British Library, London, England}

The manuscript collections in the British Library hold the letters exchanged between 1680 and 1690 by John Caryll and his sister Mary Teresa, then abbess of the Benedictine community of Dunkirk (Add Mss 28226 and 28227). These letters, written in English, cover various aspects of monastic life in exile: they give details about the living conditions of the community and demonstrate how difficult it was for the abbess to obtain the regular payment of the dowries and pensions due to the convent. But this correspondence also shows the emotional ties that continued to bind nuns to their families, through the exchange of small gifts or expression of concern about health problems, for example. Such letters are not often found in conventual archives, which is why this collection is so precious. 